\title{
Exploiting Multidisciplinary Conferences in Radiology: Teaching and Learning Opportunities for Medical Students, Radiologists and Clinicians
}

\author{
Ilona Petsch ${ }^{1 *}$, Aglaé Velasco González ${ }^{2}$, and Boris Buerke ${ }^{3}$ \\ ${ }^{1}$ Department of Radiology, Medical Faculty, University of Muenster, and University Hospital \\ Muenster, Muenster, Germany \\ 2 Department of Radiology, Neuroradiology, Medical Faculty, University of Jena, and \\ University Hospital Jena, Jena, Germany \\ ${ }^{3}$ Head of Department of Diagnostic and Interventional Radiology and MR-Tomography, \\ Klinikum Guetersloh, Guetersloh, Germany, and Department of Radiology, Medical Faculty, \\ University of Muenster, and University Hospital Muenster, Muenster, Germany
}

\section{ARTICLE INFO}

\section{Keywords:}

Multidisciplinary Conference.

Teaching Opportunities

Medical Education

Academic Radiology

Student Interaction

\begin{abstract}
Multidisciplinary conferences (MCs) including tumor boards (TBs) holding teaching and learning opportunities for medical knowledge should be exploited as educational settings for medical students in radiology. A total of $108 \mathrm{MCs}$ in radiology were analysed on interaction among students, radiologists and clinicians by non-participatory observation in 2019. Data were documented with a standardised observation sheet on criteria of teaching and learning interaction, then categorised and coded. The qualitative analysis was outlined based on two modified pedagogical principles of proactive learning, and teaching and learning processes. Results show that medical students join MCs on their own initiative. However, participation is passive. Interaction with radiologists and clinicians is limited. Although radiologists encourage students to join clinical discussions, to ask questions, and to assist in preparation of case demonstrations, students rarely seize the opportunity. The paper concludes that student interaction with radiologists and clinicians is limited regarding radiology and other medical disciplines. Students should be engaged in clinical discussions; be integrated in assisting radiologists in preparation and follow-up of case demonstrations to learn about imaging; be guided in case demonstrations to understand that clinical decisions depend on information in imaging. MCs can be exploited for teaching and proactive learning by students, radiologists and clinicians.
\end{abstract}

\section{Introduction}

Medical students serving clerkships or practical electives in radiology departments should experience real-life educational settings. Radiologists play an indispensable thus central role at multidisciplinary conferences (MCs) including tumor boards (TBs) (Collins, 2009; Munk, 2016). Students are invited to participate in MCs to encourage a proactive learning approach (Arnold, 2015), for MCs can be identified as potential educational settings (Prideaux et al., 2000; Steinert et al., 2015). These hold teaching and learning opportunities to acquire medical

* Corresponding Author E-Mail Address: ipetsch@uni-muenster.de

(C) The Author(s). 2020 Open Access. This article is licensed under a Creative Commons Attribution 4.0 International License. 
knowledge and competent decision making for clinical practice (Subramaniam \& Gibson, 2007; Haupt \& Antonites, 2020), as useful opportunities throughout medical school.

We have noticed that despite medical teaching is gaining importance, an increase in high workload or shortage in clinical staff in radiology affect teaching, and consequently learning in its quantity (Petsch et al., 2020a). There are many publications on optimising medical teaching at large, yet studies on teaching in imaging and its specialities of diagnostic and interventional radiology need further input (Rahim \& Ros, 2016). We therefore intend to contribute to optimising medical teaching in radiology. Radiology departments should exploit MCs for teaching (Hammick et al., 2009), giving medical students the real-life opportunity to gain medical knowledge. Articles on academic radiology from 2000 to 2020 cover various concepts on minimising teacher-centred approaches which lead to passive learning (Harden \& Laidlaw, 2013; Wirth et al., 2018; Minghong et al., 2019), or fostering interactive teaching (Collins, 2007; Rahim \& Ros, 2016; Wirth et al., 2018). Proposals on organising clerkships (Kasch et al., 2016), practical electives (Francavilla et al., 2016), and early implementing of radiology in medical studies aim at increasing the interest in diagnostic and interventional radiology as a medical discipline (Retrouvey et al., 2018; Kreiser et al., 2019). Besides intending to optimise educational attitudes (Gunderman \& Hafeez, 2010; Arnold, 2015), radiologists call for an interdisciplinary teaching approach cooperating with other medical disciplines (Dettmer et al., 2015; ESR, 2015; Petsch et al., 2020a). However, radiology's distinct and crucial standing as a medical discipline (Buerke et al., 2012; Dettmer et al., 2015), and its teaching role should be emphasised (Gunderman et al., 2003). We attempt to explore how MCs can be exploited as potential educational settings for medical students in radiology by applying the modified pedagogical principles of proactive learning, and teaching and learning processes (Schüßler, 2012).

\section{Methods}

A total number of $108 \mathrm{MCs}$ and TBs in radiology, with a duration of 60 minutes each and 18 weeks, were analysed on interaction among medical students, radiologists and clinicians in 2019. Included in the analysis were MCs and TBs on thorax, myeloma and lymphoma, head and neck, gynaecology, urology, neurology, neurosurgery, neuro oncology, neurovascular, as well as radiology and nuclear medicine conferences on positron emission tomography and computed tomography (PET-CT) and positron emission tomography and magnetic resonance tomography (PET-MRI).

Analysis was conducted by means of non-participatory observation during MCs and TBs by one of the authors (I.P.). Observation was passive without interacting in teaching or learning situations, and was announced prior to each observation. No personal behaviour was documented or processed. MCs were conducted by two of the authors (B.B., A.V.) as senior consultants in their clinical routine in radiology. MCs were joined by a number of maximum 5 medical students each.

Qualitative analysis was outlined based on the two modified pedagogical principles as proactive learning, and teaching and learning processes from the German acronym "ERMÖGLICHEN" as in "facilitate" by Schüßler (Schüßler, 2012). Principles were chosen to add to practice-oriented teaching in radiology. Both principles are applied in adult education to guide teaching professionals, and to support adult learners in acquiring and developing knowledge. Deductive reasoning was supported by literature from adult, higher and medical education, and literature on teaching radiology.

Data were documented during each $\mathrm{MC}$ on a standardised observation sheet on the following criteria: participation, interaction, questions and answers, communication, interest, additional (table 1). Elaboration of the gathered data was categorised, verbally coded and interpreted. Only frequent results were included in the analysis; however, these were not handled in a 
specific hierarchy in the results section. The period of analysis was terminated when no further profound findings on interaction in teaching and learning could be gathered.

\section{Results}

With regards to the criteria, the following results were reached:

\subsection{Proactive Learning}

Medical students join MCs and TBs on their own initiative, and on an optional basis. Student interaction with radiologists and clinicians is largely limited, and participation of students is passive, insofar as they are usually seated in the last rows. Students mainly interact with senior consultant radiologists by asking questions on differential diagnoses regarding demonstrated cases preceding or following MCs. Although most senior consultants offer to take interposed questions during MCs, students rarely seize this opportunity. Neither senior consultants or specialists in radiology are approached with questions beforehand or afterwards. Questions posed by radiologists are adapted to students' knowledge base; e.g. questions about pneumothorax on chest projection radiographs would be addressed to students in clerkships, rather than questions about contrast enhancement in CT scans and lymphoma in PET-CT scans directed at students completing their electives. If scheduling of MCs is tight, students appear to be more reluctant to interact. Students having previously voiced designated specialities, appear to be joining respective MCs. If for instance oncology is pursued as a speciality, mainly TBs in myeloma and lymphoma or head and neck are attended; if gynaecology is pursued, students often visit gynaecology or urology TBs.

\subsection{Teaching and Learning Processes}

Medical students are explicitly given the opportunity to participate at MCs and TBs to assist in preparation and follow up of case demonstrations with senior consultant radiologists. Students are invited to join conference discussions with radiologists and clinicians, and are offered to ask interposed questions on differential diagnoses or clinical patterns with the chance for rapid answers. Although this constitutes potential learning experiences allowing instant and precise answers - other than learning from the book or surfing online for answers -, students infrequently seize this opportunity during or following MCs. We have further noticed that students rarely request additional explaining on e.g. therapeutic decisions, clinical options or consequences. Clinicians occasionally contribute to explanations by radiologists, or address students with case-related questions of clinical relevance. Such contributions are rare, however. Student interaction with radiologists and clinicians also appears to be scarce when workload in radiology is high or increasing. With shortage in staff, teaching time in clinical routine seems insufficient, and even less so during MCs. Nevertheless, students report that by joining MCs repeatedly, the role of radiologists and their multidisciplinary interaction with clinicians become clearer. Students report that compared to discussing imaging cases in curricular seminars and courses, authentic clinical discussions among medical doctors can be followed in real-life settings.

\section{Discussion}

Combined with the literature, we present following arguments:

\subsection{Proactive Learning}

The fact that medical students frequently attend MCs and TBs can be valued constructively owing to the initiative they show in learning (Arnold, 2015). However, as clinical teachers and academic professionals we should add to minimising passive attendance (Rahim \& Ros, 2016; Minghong et al., 2019). By motivating students to engage in discussions more actively (McLeod \& Steinert, 2015; Pagani \& Morin, 2020; Petsch et al., 2020b), we can stimulate a 
proactive learning attitude towards radiology (Collins, 2007; Arnold, 2015; Rahim \& Ros, 2016; Goulao, 2020). We will make students feel welcome by inviting them to be seated next to medical doctors, and by encouraging them to ask related - or even burning - interposed questions. We can do so by asking students to assist in preparation and follow-up of case demonstrations for MCs (Petsch et al., 2020a, 2020b), and by integrating these future medical doctors in interactions with clinicians involved. Hence, we would deliver on more interactive teaching than simply asking students on possible differential diagnoses and by leaving it at short explanatory clinical answers.

Considering the fact that MCs are not curricular classes in medical studies, but are held for case demonstrations, clinical evaluations and therapeutic decisions in patient care, factors such as effectivity, cost efficiency and certification for attending medical and academic staff are significant. Hence focus will not primarily be on teaching medical students. Despite this emphasis on patient management, we argue that teaching can still be integrated into $\mathrm{MC}$ procedures, e.g. by having students assist senior consultant radiologists in case preparations. Such activities contain opportunities for students to understand and learn competent, efficient and timely case demonstrating, and to be exposed to a wide variety of clinical pictures in imaging (Petsch et al., 2020a, 2020b). They will get an idea which particular questions must be directed at radiologists at $\mathrm{MCs}$, and which extracted information must be directed at clinicians crucial for diagnostic interpretations, therapeutic decisions or treatments (Gunderman et al., 2003; Munk, 2016; Buerke B, unpublished data, 2019; Petsch et al., 2020b). Students should be lead to understand the crucial role of radiology in patient management and with patients from all clinical departments passing through radiology (Branstetter IV et al., 2007; Buerke et al., 2012; Munk, 2016), and its role in MC teams in patient management (Gunderman \& Hafeez, 2010; Slanetz \& Mullins, 2016).

By involving medical students in preparation (Petsch et al., 2020b), MCs can be identified as potential practice-oriented settings for medical learning (Subramaniam \& Gibson, 2007; Haupt \& Antonites, 2020), and can be exploited as an educational introduction to general radiology. We want to emphasise that demonstrating cases in imaging is not merely presenting radiological imaging. It entails clinical elaborating of information - information which is a sound and compressed extract of the comprehensive report of the radiologist, crucial for clinical decisions with the clinical disciplines involved (Buerke B, unpublished data, 2019; Petsch et al., 2020b). Competent case demonstration means timely interaction with clinical colleagues inasmuch as radiologists present, analyse and discuss imaging cases (Collins, 2009) in an efficient and effective procedure. Hence students should be guided in effective contributing to reports and modifications as follow-up assistance to understand that clinical decisions at MCs depend on imaging in radiology (Petsch et al., 2020a, 2020b).

Besides self-study on imaging, e.g. with study books, online medical sites or PACS, medical students should be guided in understanding and demonstrating cases (Slanetz, 2011; Rahim \& Ros, 2016; Petsch et al., 2020a, 2020b). Assigned tasks in assisting senior consultants can vary from checking patient lists for MCs, simply following image interpreting (Kelly \& Slanetz, 2015), and taking notes during MC procedures. Tasks should be adapted to students' knowledge base (Rahim \& Ros, 2016), so as to generate fruitful teaching, practicing and learning (Haupt $\&$ Antonites, 2020). Tasks should always be adequate for MC settings and non-interrruptive. Students should develop communicative skills in radiology (Slanetz, 2011; Rahim \& Ros, 2016), and for future clinical practice in all medical disciplines (Gunderman et al., 2003; ESR, 2017; Haruta \& Yamamoto, 2020).

Such self-organised and responsible learning will prepare medical students completing their electives for future clinical practice within and outside of radiology (Schüßler, 2012; Arnold, 2015). Whether radiology will be a career option or not, they will need to know about the role of radiology (Gunderman et al., 2003; Munk, 2016), for medical doctors are always in touch 
with radiologists. Training to hold case demonstrations can generate more attentive student participation, while proceedings of radiologists at MCs gradually become more selfexplanatory. Assigning assisting tasks can be an incentive for radiologists with overly busy workload or schedules, as proactive students can be of help with small but timely handlings, assisting in case interpreting (Gunderman \& Harprit, 2013; Munk, 2016; Petsch et al., 2020a, 2020b), or in patient care (Harden \& Laidlaw, 2013), e.g. by inserting central lines. Assistance for specific MCs can be motivating for students with already designated specialities.

\subsection{Teaching and Learning Processes}

Limited interaction between medical students and radiologists or clinicians at MCs and TBs means that both settings are not entirely identified to be generated for medical education (Petsch et al., 2020b). We argue that MCs are available as potential educational settings for radiology and medical studies - educational opportunities that could be well seized for teaching (Schüßler, 2012; Arnold, 2015). Medical students are invited to participate at MCs and are offered the opportunity to assist in case preparation and follow-up as potential learning situations. By actively engaging, they can develop radiological and medical knowledge, and can profit from looking at clinical pictures, radiological procedures and interventions from a radiologist's point of view.

Although medical students are reluctant to actively place questions, they report benefiting from repeatedly following case demonstrations and authentic discussions than merely attending regular imaging seminars or courses. Even with participation being passive (Petsch et al., $2020 \mathrm{~b}$ ), following MCs is described to help gaining knowledge in imaging and clarifying the role of the radiologist. If learning benefits are expressed from only passive yet frequent attendance, this indicates that senior consultant radiologists and specialists should enhance open-minded and flexible student engagement in case analysis and clinical discussions (Collins, 2009; Haupt \& Antonites, 2020; Pagani \& Morin, 2020). By increasing student integration, welcoming questions on clinical explanations, radiological procedures and therapies in radiological and neuroradiological interventions (Gunderman et al., 2003; Velasco González et al., 2020), we signalise support of student development of self-initiative and responsibility in gaining medical knowledge in radiology (Newman \& Peile, 2002; McLeod \& Steinert, 2015; Petsch et al., 2020b).

We agree that radiology education should be made more present and interactive in the big picture of medical education (Gunderman \& Hafeez, 2010; Rahim \& Ros, 2016), since radiology has an interface function interacting with all medical disciplines (Gunderman et al., 2003; Munk, 2016). This scientific setting offers teaching and learning opportunities yet unexploited (Schüßler, 2012), which could be utilised for multidisciplinary teaching with different specialists (Prideaux et al., 2000; Hammick et al., 2009; Retrouvey et al., 2018) attending MCs. Clinicians already address medical students in radiology with input from different specialities. This does count towards teaching, so that we should enhance this multidisciplinary approach. We prepare these future medical doctors for interdisciplinary medical work as non-radiologists and radiologists all the same.

Results of other studies indicate that medical students perceive radiology as interdisciplinary, providing another argument to adjust teaching in radiology with a multidisciplinary approach (Gunderman \& Hafeez, 2010; ESR, 2015; Kasch et al., 2016), and for integrating teaching at MCs. We propose making MCs and TBs an integral element of rotation schedules in clerkships and electives to guide students in demonstrating cases (Petsch et al., 2020a, 2020b). For instance, students rotating in computer tomography or magnetic resonance tomography should join senior consultants in radiology and nuclear medicine in radiological and nuclear medical conferences on PET-CT or PET-MRI. We should create a learning benefit for students by arranging radiology teaching at MCs with nuclear medicine and radiotherapy (Dettmer et al., 
2015; Petsch et al., 2020a) - as our sister disciplines in imaging. Students serving their elective period in our department of radiology are scheduled for a mandatory rotation in radiotherapy and nuclear medicine. Cooperating with both disciplines in rotation planning particularly for practical electives (Francavilla et al., 2016), multidisciplinary teaching is facilitated and students are encouraged to join respective MCs (Hammick et al., 2009).

With increasing workload, tight schedules and shortage in staff in clinical routine, interaction with medical students is consequently scarce at MCs (Petsch et al., 2020a). We argue that radiologists and clinicians should generally not be required to go into additional teaching at MCs per se besides curricular teaching, since patient management is the foremost focus. So again the argument of involving students in assisting in routine tasks (Visscher et al., 2015), preparation and follow-up activities comes into play (Gunderman \& Harprit, 2013; Petsch et al., 2020b). This way students would actively contribute to educational goals of MCs (O'Brien et al., 2017; Goulao, 2020). Moreover, students get to train communicative skills in medical contexts evolving around diagnostic and therapeutic decisions (Gunderman et al., 2003; Rahim \& Ros, 2016; ESR, 2017; Haruta \& Yamamoto, 2020) - skills imperative for their upcoming residency. Instead of expecting medical doctors to deliver on additional teaching when deciding on patient diagnoses and therapies, students can be involved in multidisciplinary communication and interaction. Teaching in radiology can be combined with teaching in the participating disciplines by cooperating and adjusting topics or tasks (Schüßler, 2012; Rahim \& Ros, 2016, Petsch et al., 2020a).

\subsection{Overall Discussion}

Since medical students in radiology attend MCs and TBs on their own initiative (Petsch et al., $2020 \mathrm{~b}$ ), this indicates an early interest in radiological imaging and interventions (Kreiser et al., 2019). We need to support students in gaining an understanding for the significance of radiology for all medical disciplines (Gunderman et al., 2003; Branstetter IV et al., 2007; Munk, 2016). Student interaction with radiologists and clinicians should be supported to generate teaching and learning in radiology and the specialities involved, by actively engaging students in radiology topics during multidisciplinary discussions (Collins, 2007; Pagani \& Morin, 2020; Petsch et al., 2020b). Students should be integrated in assisting senior consultant radiologists in effective preparation and follow-up of case demonstrations for MCs to become familiar with radiological imaging and neuroradiological interventions (Petsch et al., 2020a; Velasco González' et al., 2020). Students should be guided in routine tasks and procedures in radiology (Visscher et al., 2015; Dettmer et al., 2017), and in understanding case demonstrations (Slanetz, 2011; Rahim \& Ros, 2016; Petsch et al., 2020a). Students should be supported in contributing to case reports and modifications in radiology so as to understand elaborating extracted information from imaging. We want to emphasise that diagnostic and therapeutic decisions made by clinicians depend on timely and efficient case demonstrations of radiologists as part of MC teams (Slanetz \& Mullins, 2016; Wirth et al., 2018; Petsch et al., 2020b). High workload, tight schedules and staff shortage in clinical routine can affect interaction among medical students, radiologists and clinicians at MCs (Petsch et al., 2020a). We aim at exploiting MCs and TBs in radiology as real-life and potential educational settings by seizing teaching, practicing and learning opportunities (Schüßler, 2012; Arnold, 2015; Haupt \& Antonites, 2020), and making it an integral element for clerkships and practical electives in radiology. The modified pedagogical principles of proactive learning, and teaching and learning processes, can be applied to support a real-life and multidisciplinary teaching approach (Schüßler, 2012). 


\section{Limitations}

The observation conducted by one person may not deliver absolute objectivity. Although interpretation of the results was looked at by all co-authors attempting to include different perspectives, we cannot guarantee covering all chances and limitations possible in this study. The analysis was influenced by experiences and expectations in teaching approaches from adult education, hence pedagogical perspectives still might need to harmonise with medical teaching in clinical routine. Although ensuring the necessary distance to proceed neutrally, nonparticipatory observation can be criticised as limiting for lacking interaction with participants. The field analysis is limited to MCs and TBs, which needs to be expanded so as to cover teaching in radiology on a larger scale. Conducting a qualitative analysis is time-consuming, so this could be a hurdle for medical staff in clinical routine.

\section{Conclusions}

Medical students attending MCs and TBs in radiology on their own initiative indicates an interest in imaging for medical work, which should be supported. Since student interaction with radiologists and clinicians is limited and affected by high workload and staff shortage in clinical routine, teaching and learning in radiology and other medical disciplines should be generated at MCs. Students should be: engaged in multidisciplinary discussions with radiologists and clinicians; be integrated in assisting radiologists in preparation and follow-up of case demonstrations to learn about clinical and interventional imaging; be guided in timely and efficient case demonstrations and in contributing to case reports to understand that diagnostic and therapeutic decisions at MCs depend on extracted information from imaging. MCs and TBs can be exploited as potential teaching and learning settings for radiologists, clinicians and medical students to generate multidisciplinary teaching and proactive learning in radiology.

\section{Disclosure Statement}

The authors report no conflicts of interest. The first author and co-authors alone are responsible for the content and writing of this article.

\section{Acknowledgments}

We thank Professor Walter Heindel, director of the Department of Radiology, for perceiving teaching radiology to medical students in a positive light. Ilona Petsch thanks Thomas Prescher, Professorship for Vocational Education in Health Care, Wilhelm Löhe University of Applied Sciences, Fuerth, for critical feedback on the methods section. She especially thanks Professor Boris Buerke and Dr. Aglaé Velasco González for sharing their medical experience and realistic input that helped to see MCs and TBs from a radiologist's perspective.

\section{References}

Arnold, R. (2015). Bildung nach Bologna! Die Anregungen der europäischen Hochschulreform [Education after Bologna! The suggestions of the European academic Reform]. Wiesbaden: Springer, 65, 71, 146. German. [accessed 2020 May 08]. http://dx.doi.org/10.1007/978-3658-08978-8

Branstetter, BF. 4th, Faix, LE., Humphrey, AL., Schumann, JB. (2007). Preclinical medical student training in radiology: the effect of early exposure. AJR Am J Roentgenol. 188(1),W914. http://dx.doi.org/10.2214/AJR.05.2139

O'Brien, BC., Patel, SR., Pearson, M., Eastburn, AP., Earnest, GE., Strewler, A., Gager, K., Manuel, JK., Dulay, M., Bachhuber, MR., Shunk, R. (2017). Twelve tips for delivering successful interprofessional case conferences. Med Teach. 39(12),1214-1220. http://dx.doi.org/10.1080/0142159X.2017.1344353 
Buerke, B., Mellmann, A., Kipp, F., Weßling, J. (2012). Hygienic Aspects in Radiology: What the Radiologist Should Know [Hygiene in der Radiologie: Was der Radiologe wissen sollte]. Rofo 184(12),1099-1109. http://dx.doi.org/10.1055/s-0032-1325444

Collins, J. (2007). Designing learning experiences. Radiographics. 27(5),1511-1517. http://dx.doi.org/10.1148/rg.275065208

Collins, J. (2009). Lifelong learning in the 21st century and beyond. Radiographics. 29(2),613622. http://dx.doi.org/10.1148/rg.292085179

Dettmer, S., Weidemann, J., Fischer, V., Wacker, FK., German Association of Chairmen in Academic Radiology (KLR), German Radiological Society (DRG) - Executive Board. Adam, G., Antoch, G., Barkhausen, J., Beer, M., et al. (2015). Integrative teaching in radiology - a survey. Rofo. 187(4),260-268. http://dx.doi.org/10.1055/s-0034-1399193

Dettmer, S., Fischer, V., Paeßens, C., Meyer, S., Wacker, FK., Rodt, T. (2017). Who will be the Radiologists of Tomorrow? A survey of radiology during the "Practical Year" in Germany. Rofo. 189(10),967-976. http://dx.doi.org/10.1055/s-0043-112338

(ESR) European Society of Radiology: Teaching undergraduates radiology: a guidance paper for teachers of undergraduates. (2015). Vienna: European Society of Radiology; [accessed 2020 May 08]. https://www.myesr.org/media/188

(ESR) European Society of Radiology: Curriculum for undergraduate radiological education. U-level curriculum. (2017). Vienna: European Society of Radiology; [accessed 2020 May 08]. https://www.myesr.org/media/229

Francavilla, ML., Arleo, EK., Bluth EI., Straus, CM., Reddy, S., Recht, MP. (2016). Surveying Academic Radiology Department Chairs Regarding New and Effective Strategies for Medical Student Recruitment. AJR Am J Roentgenol. 207(6),1171-1175. http://dx.doi.org/10.2214/AJR.16.16445

Goulao, MDF. (2020). Online Learning Environments and Some Pedagogical Implications. EJTE. 2(2),60-74. http://dx.doi.org/10.33422/ejte.v2i2.198

Gunderman, RB., Siddiqui, AR., Heitkamp, DE., Kipfer, HD. (2003). The vital role of radiology in the medical school curriculum. AJR Am J Roentgenol. 180(5),1239-1242. http://dx.doi.org/10.2214/ajr.180.5.1801239

Gunderman, RB., \& Hafeez, I. (2010). Radiology education: a chronicle of support and success through the RSNA Research and Education Foundation. Radiographics. 30(5), a1157-1161. http://dx.doi.org/10.1148/rg.305105167

Hammick, M., Olckers, L., Campion-Smith, C. (2009). Learning in interprofessional teams: AMEE Guide no 38. Med Teach. 31(1),1-12. http://dx.doi.org/10.1080/01421590802585561

Harden, RM., \& Laidlaw, JM. (2013). Be FAIR to students: four principles that lead to more effective learning. Med Teach. 35(1), 27-31. http://dx.doi.org/10.3109/0142159X.2012.732717

Haruta, J., \& Yamamoto, Y. (2020). Realist approach to evaluating an interprofessional education program for medical students in clinical practice at a community hospital. Med Teach. 42(1),101-110. http://dx.doi.org/10.1080/0142159X.2019.1665633

Haupt, S., \& Antonites, A. (2020). Factors Influencing Innovation Adoption in a Higher Education Institution. EJTE. 2(2),60-74. http://dx.doi.org/10.33422/ejte.v2i2.200

Kasch, R., Wirkner, J., Hosten, N., Hinz, P., Napp, M., Kessler, R. (2016). Subinternship in Radiology - A Practical Start to the Specialization? Rofo. 188(11),1024-1030. http://dx.doi.org/10.1055/s-0042-113612 
Kelly, AM., \& Slanet, PJ. (2015). Radiology Education: Creating Tomorrow's Radiologists with Yesterday's Budgets! Acad Radiol. 22(10),1211-1213. http://dx.doi.org/10.1016/j.acra.2015.08.001

Kreiser, K., Gehling, K., Zimmer, C. (2019). Simulation in Angiography - Experiences from 5 Years Teaching, Training, and Research. Rofo. 191(6),547-552. http://dx.doi.org/10.1055/a0759-2248

McLeod, P., \& Steinert, Y. (2015). Twelve tips for curriculum renewal. Med Teach. 37(3),232238. http://dx.doi.org/10.3109/0142159X.2014.932898

Minghong, B., Zhibiao, Z., Jingru, Y., Yaping, W. (2019). Comparison of case-based learning and traditional method in teaching postgraduate students of medical oncology. Med Teach. 41(10),1124-1128. http://dx.doi.org/10.1080/0142159X.2019.1617414

Munk, PL. (2016). A Place in the Sun: The Importance of Radiology in Multidisciplinary Conference. Can Assoc Radiol J. 67(3),203. http://dx.doi.org/10.1016/j.carj.2016.06.002

Newman, P., \& Peile, E. (2002). Valuing learners' experience and supporting further growth: educational models to help experienced adult learners in medicine. BMJ. 325(7357),200202. http://dx.doi.org/10.1136/bmj.325.7357.200

Pagani, V., \& Morin, A. (2020). Didactics and Self-Assessment: An Innovative Proposal for The University of Trento. EJTE. 2(2),18-23. https://doi.org/10.33422/ejte.v2i2.196

Petsch, I., González Velasco, A., Heindel, W., Buerke, B. (2020a). Making Medical Teaching Interactive: Catering Learning Needs in Radiology. In: Abstracts of ARETL 2020 Virtual Conference; Berlin, Germany, 2020 March 20-22. Abstract 370. 2nd International Conference on Advanced Research in Education, Teaching and Learning: Vilnius, Lithuania. https://www.dpublication.com/abstract-of-2nd-aretl/62-ar/

Petsch, I., González Velasco, A., Heindel, W., Buerke, B. (2020b). Teaching radiology: Integrating medical students by increasing communication. In: Abstracts of ARETL 2020 Virtual Conference; Berlin, Germany, 2020 March 20-22. Abstract 372. 2nd International Conference on Advanced Research in Education, Teaching and Learning: Vilnius, Lithuania. https://www.dpublication.com/abstract-of-2nd-aretl/62-ar/

Prideaux, D., Alexander, H., Bower, A., Dacre, J., Haist, S., Jolly, B., Norcini, J., Roberts, T., Rothman, A., Rowe, R., Tallett, S. (2000). Clinical teaching: maintaining an educational role for doctors in the new health care environment. Med Educ. 34(10),820-826. http://dx.doi.org/10.1046/j.1365-2923.2000.00756.x

Rahim, S., \& Ros, P. (2016). Moving away from spoon-feeding as a teaching style in radiology. AJR Am J Roentgenol. 207(6),1232-1238. http://dx.doi.org/10.2214/AJR.16.16694

Retrouvey, M., Trace, AP., Goodmurphy, CW., Shaves, S. (2018). Journal Club: Redefining the radiology curriculum in medical school: vertical integration and global accessibility. AJR Am J Roentgenol. 210(1),118-122. http://dx.doi.org/10.2214/AJR.17.18211

Schüßler, I. (2012). Ermöglichungsdidaktik - Grundlagen und zentrale didaktische Prinzipien [Didactics of Facilitation - Basics and central didactic Principals] In: Gieseke W, Nuissl E, Schüßler I, editors. Reflexionen zur Selbstbildung. Festschrift für Rolf Arnold [Reflections on Self-Education. Commemorative Volume in Honour of Rolf Arnold]. Bielefeld: Bertelsmann, 138-145. German. [accessed 2020 May 08]. http://www.die-bonn.de/id/10828 
Slanetz, PJ. (2011). Teaching appropriate, cost-effective care using the American College of Radiology appropriateness criteria. Acad Med. 86(11),e14. http://dx.doi.org/10.1097/ACM.0b013e318231508e

Slanetz, PJ., \& Mullins, ME. (2016). Radiology Education in the Era of Population-based Medicine in the United States. Acad Radiol. 23(7),894-7. http://dx.doi.org/10.1016/j.acra.2016.01.017

Steinert, Y., \& Macdonald, ME. (2015). Why physicians teach: giving back by paying it forward. Med Educ. 49(8),773-82. http://dx.doi.org/10.1111/medu.12782

Subramaniam, RM., \& Gibson, RN. (2007). Radiology teaching: essential of a quality teaching programme. Australas Radiol. 51(1),42-45. http://dx.doi.org/10.1111/j.14401673.2006.01657.x

Velasco González, A., Buerke, B., Görlich, D., Fobker, M., Rusche, T., Sauerland, C., Meier, N., Jeibmann, A., McCarthy, R., Kugel, H., Sporns, P., Faldum, A., Paulus, W., Heindel, W. (2020). Clot Analog Attenuation in Non-contrast CT Predicts Histology: An Experimental Study Using Machine Learning. Transl Stroke Res. http://dx.doi.org/10.1007/s12975-01900766-z.

Visscher, KL., Nassrallah, G., Faden, L., Wiseman, D. (2015). The Exposure dilemma: qualitative study of medical student opinions and perceptions of radiology. Can Assoc Radiol J. 66(3),291-297. http://dx.doi.org/10.1016/j.carj.2014.12.008

Wirth, S., William, YA., Paolini, M., Wirth, K., Maxien, D., Reiser, M., Fischer, MR. (2018). Improvement of radiological teaching - effects of focusing of learning targets and increased consideration of learning theory knowledge. Rofo. 190(2),161-174. http://dx.doi.org/10.1055/s-0043-119037

\section{Notes on contributors}

Ilona Petsch, MA Adult Education, CELTA, Dr. rer. medic candidate, Academic Coordinator, Department of Radiology, University of Muenster, and University Hospital Muenster, Muenster, Germany

Aglaé Velasco González, MD, is a Senior Consultant Neuroradiologist, Interventional Neuroradiologist, Department of Radiology, Neuroradiology, University of Jena, and University Hospital Jena, Jena, Germany

Boris Buerke, MD, MHBA, is Professor and Head of Department of Diagnostic and Interventional Radiology and MR-Tomography, Klinikum Guetersloh, Guetersloh, Germany, and Professor and a Senior Consultant Radiologist, Department of Radiology, University of Muenster, and University Hospital Muenster, Muenster, Germany 
Table 1

\section{Appendix}

Observation sheet with modified pedagogical principle

\begin{tabular}{|c|c|c|}
\hline \multicolumn{2}{|c|}{$\begin{array}{l}\text { MC/TB: } \\
\text { DATE: } \\
\text { NO. OF STUDENTS: } \\
\text { OBSERVING STAFF: }\end{array}$} & \\
\hline PEDAGOGICAL PRINCIPLE & \multicolumn{2}{|c|}{ DOCUMENTATION OF NON-PARTICIPATORY OBSERVATION } \\
\hline Teaching and learning processes & Teaching: radiologists \& clinicians & Learning: medical students \\
\hline $\begin{array}{l}\text { HOW DO THESE } \\
\text { CRITERIA SHOW? } \\
\text { List in slots to the right. Turn if } \\
\text { needed. } \\
\text { 1. participation } \\
\text { 2. interaction } \\
\text { 3. Q\&A } \\
\text { 4. communication } \\
\text { 5. interest } \\
\text { 6. additional }\end{array}$ & $\begin{array}{l}\text { e.g. } \\
\text { 2. basic explaining for students } \\
\text { would have been possible: } \\
\text { radiologist }+ \text { oncologists discuss } \\
\text { contrast-enhanced CT scan of } \\
\text { lymphomatous lymph node } \\
\text { 2. radiologist offers two students to } \\
\text { join preparing next board } \\
\text { 3. radiologist encourages questions } \\
\text { 6. busy case schedule, radiologist } \\
\text { demonstrating in } 4 \text { conferences }\end{array}$ & $\begin{array}{l}\text { e.g. } \\
1+2 . \text { do not join in, no oral } \\
\text { contribution } \\
\text { 3. reluctant to ask questions, little } \\
\text { time for queries } \\
\text { 4+5. students could inquire: spe- } \\
\text { cialist asks question on abdominal } \\
\text { entity }\end{array}$ \\
\hline $\begin{array}{l}\text { KEY QUESTIONS } \\
\text { List in slots to the right. Turn if } \\
\text { needed. } \\
\text { 7. How can teaching be } \\
\text { implemented? } \\
\text { 8. How can learning be } \\
\text { generated? } \\
\text { 9. How can multidisciplinary } \\
\text { teaching look like? }\end{array}$ & $\begin{array}{l}\text { e.g. } \\
\text { 7. radiologist explains differential } \\
\text { diagnoses (clinician could explain } \\
\text { therapeutic consequences) } \\
\text { 9. diagnoses, therapeutic ap- } \\
\text { proaches and decisions are illus- } \\
\text { trated from different clinical per- } \\
\text { spectives }\end{array}$ & $\begin{array}{l}\text { e.g. } \\
\text { 8. students could actively ask about } \\
\text { further differential diagnoses and } \\
\text { therapeutic consequences }\end{array}$ \\
\hline $\begin{array}{l}\text { ELABORATION: } \\
\text { CRITERIA } \\
\rightarrow \text { 1. participation } \\
\rightarrow \text { 2. interaction } \\
\rightarrow \text { 3. Q\&A } \\
\rightarrow \text { 4. communication } \\
\rightarrow \text { 5. interest } \\
\rightarrow \text { 6. additional }\end{array}$ & $\begin{array}{l}\text { e.g. } \\
\text { 2. interaction among radiologist, } \\
\text { clinicians and students is limited } \\
\text { 2+3. radiologist attempts to create } \\
\text { teaching and learning opportunities } \\
\text { 6. due to busy conference schedul- } \\
\text { ing with many cases, teaching inter- } \\
\text { action is not generated }\end{array}$ & $\begin{array}{l}\text { e.g. } \\
\text { 1+2. despite attending on their } \\
\text { own initiative, active participation } \\
\text { and contribution are limited } \\
\text { 3. students seem to go with tight } \\
\text { scheduling and ask fewer questions } \\
\text { 4+5. students should seize learning } \\
\text { opportunities, ask interposed ques- } \\
\text { tions when possible }\end{array}$ \\
\hline $\begin{array}{l}\text { ELABORATION: KEY } \\
\text { QUESTIONS } \\
\rightarrow \text { 7. teaching } \\
\rightarrow \text { 8. learning } \\
\rightarrow \text { 9. multidisciplinary inter- } \\
\quad \text { acting }\end{array}$ & $\begin{array}{l}\text { e.g. } \\
\text { 7. by pointing out differential diag- } \\
\text { noses, students are asked to draw on } \\
\text { their medical knowledge base } \\
\text { 9. radiologist referring to differen- } \\
\text { tial diagnoses and clinicians adding } \\
\text { possible therapeutic decisions } \\
\text { marks medical teaching from a radi- } \\
\text { ologist's and specialist's perspective }\end{array}$ & $\begin{array}{l}\text { e.g. } \\
\text { 8. by inquiring radiological and } \\
\text { clinical details, students can ac- } \\
\text { quire knowledge on imaging and } \\
\text { medical education in general }\end{array}$ \\
\hline
\end{tabular}




\begin{tabular}{|c|c|c|}
\hline \multirow{2}{*}{$\begin{array}{l}\text { PEDAGOGICAL PRINCIPLE } \\
\text { Proactive learning } \\
\end{array}$} & \multicolumn{2}{|c|}{ DOCUMENTATION OF NON-PARTICIPATORY OBSERVATION } \\
\hline & Teaching: radiologists \& clinicians & Learning: medical students \\
\hline $\begin{array}{l}\text { HOW DO THESE } \\
\text { CRITERIA SHOW? } \\
\text { List in slots to the right. Turn if } \\
\text { needed. } \\
\text { 1. participation } \\
\text { 2. interaction } \\
\text { 3. Q\&A } \\
\text { 4. communication } \\
\text { 5. interest } \\
\text { 6. additional }\end{array}$ & $\begin{array}{l}\text { e.g. } \\
\text { 2. radiologist invites student to } \\
\text { assist in case preparation for next } \\
\text { conference } \\
\text { 3. radiologist offers to take } \\
\text { interposed questions } \\
\text { 6. radiologist holding } 5 \\
\text { conferences/boards in a row, several } \\
\text { clinicians joining all conferences in } \\
\text { a row }\end{array}$ & $\begin{array}{l}\text { e.g. } \\
1+3 . \text { students are reluctant to ask } \\
\text { for further explaining } \\
4+5 . \text { student group pays attention } \\
\text { to a discussion among clinicians }\end{array}$ \\
\hline $\begin{array}{l}\text { KEY QUESTIONS } \\
\text { List in slots to the right. Turn if } \\
\text { needed. } \\
\text { 7. How can proactive learning } \\
\text { be stimulated? } \\
\text { 8. How does lack of } \\
\text { participation show? }\end{array}$ & $\begin{array}{l}\text { e.g. } \\
\text { 7. radiologist offers student to assist } \\
\text { in follow-up of demonstrations }\end{array}$ & $\begin{array}{l}\text { e.g. } \\
\text { 7. student can take relevant notes } \\
\text { on cases } \\
\text { 8. students sit in back row, do not } \\
\text { respond to questions by any medi- } \\
\text { cal doctor }\end{array}$ \\
\hline $\begin{array}{l}\text { ELABORATION: } \\
\text { CRITERIA } \\
\rightarrow 1 \text {. participation } \\
\rightarrow \text { 2. interaction } \\
\rightarrow \text { 3. Q\&A } \\
\rightarrow \text { 4. communication } \\
\rightarrow \text { 5. interest } \\
\rightarrow 6 . \text { additional }\end{array}$ & $\begin{array}{l}\text { e.g. } \\
\text { 2. radiologist offers to utilise case } \\
\text { preparation and follow-up of } \\
\text { demonstrations for teaching and } \\
\text { learning opportunities, and attempts } \\
\text { to explore conference and board for } \\
\text { teaching radiology } \\
\text { 3. radiologist motivates students to } \\
\text { interact } \\
\text { 6. workload and case scheduling } \\
\text { affects teaching at conference today }\end{array}$ & $\begin{array}{l}\text { e.g. } \\
1+3 . \text { passive participation can be } \\
\text { detected by not asking questions } \\
\text { and for further explanations } \\
4+5 . \text { clinical discussion between } \\
\text { radiologist and clinicians is ac- } \\
\text { tively followed by students, which } \\
\text { they obviously show interest in }\end{array}$ \\
\hline $\begin{array}{l}\text { ELABORATION: KEY } \\
\text { QUESTIONS } \\
\rightarrow \text { 7. proactive learning } \\
\rightarrow \text { 8. participation }\end{array}$ & $\begin{array}{l}\text { e.g. } \\
\text { 7. radiologist invites student to ac- } \\
\text { tively contribute to follow-up tasks } \\
\text { of case demonstrations }\end{array}$ & $\begin{array}{l}\text { e.g. } \\
\text { 8. student can take up assisting } \\
\text { tasks during conference, which will } \\
\text { be of help for follow-up work with } \\
\text { radiologist }\end{array}$ \\
\hline
\end{tabular}

